\title{
Az alsó középiskolában használt angol tankönyvek szerepe a kommunikatív nyelvoktatásban két Sunshine-ból tanító alsó középiskolai tanár esettanulmánya alapján ${ }^{1}$
}

\author{
FeKete RÉkA
}

affil

\begin{abstract}
A Kairyudo kiadó gondozásában megjelenö Sunshine a Japán Oktatásügyi, Kulturális, Sport-valamint Tudomány- és Technológiaügyi Minisztérium (MEXT) által jóváhagyott alsó középiskolai tankönyvcsalád. Jelen esettanulmány két Iwate Prefektúrában a Sunshine tankönyvekböl tanitó pedagógus munkáját megfigyelve a következö kérdésekre keresi a választ: mely tulajdonságokban felel meg a tankönyv a Nemzeti Alaptanterv szempontjainak, a két pedagógus hogyan értelmezi és épiti be a tankönyv egyes jellemzöit mindennapos tanári tevékenységébe, illetve milyen módszereket alkalmaznak a tankönyv kiegészitésére. A kutatáshoz a Sunshine tankönyvek hivatalos tájékoztató kiadványa és kiegészitő brosúrája, óralátogatások, óralátogatási jegyzökönyvek, félig strukturált interjúk, tanteremi oktatási eszközök szolgáltattak alapot. A kutatási eredmények szerint a Sunshine tankönyvcsalád általánosságban megfelel a kommunikatív megközelítésnek, de a tanároknak saját ötleteikkel kell kiegésziteniük a tankönyvet.
\end{abstract}

Kulcsszavak: kommunikatív nyelvoktatás, Sunshine tankönyvcsalád, angol nyelvoktatás Japánban, alsó középiskolában használt angol tankönyvek, japán Nemzeti Alaptanterv

\section{Bevezetés}

A jelenlegi japán Nemzeti Alaptanterv a kommunikatív nyelvoktatás alapelveinek megfelelően közelíti meg a nyelvtanítást. Számos tanulmány született már a Japánban folyó nyelvoktatási reformok hatékonyságának kérdéséről (például Aspinall, 2006; Butler, 2011; Gorsuch, 2000; Humphries \& Burns, 2015; Nishino \& Watanabe, 2008; Sakui, 2004). Azonban viszonylag kevés publikáció látott napvilágot arról, hogy az alsó középiskolai angol tanárok hogyan igyekeznek értelmezni és használni a $M E X T^{2}$ által jóváhagyott, kommunikatív nyelvoktatást célzó tankönyveket.

\footnotetext{
1 Fekete Réka és James M. Hall professzor (Iwate Egyetem, Morioka, Japán) The Role of Junior High School English Textbooks in Communicative Language Teaching Based on a Case Study of Two Junior High School Teachers Teaching Sunshine (2015) címủ angol nyelvü tanulmánya alapján.

2 Japán Oktatásügyi, Kulturális, Sport-, valamint Tudomány- és Technológiaügyi Minisztérium
}

Jelen tanulmány a következő három kutatási kérdésre keresi a választ a számos alsó középiskolában használt (Gakusho, 2012), MEXT által jóváhagyott Sunshine tankönyvcsalád (Niisato és mtsai, 2011) harmadik kiadásával kapcsolatban:

1. Mely tulajdonságokban felel meg a Sunshine tankönyv harmadik kiadása a Nemzeti Alaptantervben meghatározott szempontoknak?

2. A kutatásban részt vevő két pedagógus hogyan értelmezi és építi be a tankönyv egyes jellemzőit mindennapos tanári tevékenységébe?

3. Milyen módszereket alkalmaznak a tankönyv anyagának kiegészítésére?

\section{Módszer}

\subsection{A résztvevők és az iskola}

A kutatásban ugyanazon iskola két tapasztalt tanára vett részt. Sakura (fedőnév) az adatgyűjtés idején egy 35 fős elsős osztály osztály- 
főnöke volt, heti négy órában tanítva nekik az angol nyelvet. Shouta (fedőnév) egy 30 diákból álló másodikos osztály osztályfőnökeként szintén heti négy angol órát tartott osztályában. Mindkét pedagógus esetében saját osztályuk óráin történt a megfigyelés.

\subsection{Az adatgyüjtés módja}

2014 novembere és decembere között történt az adatgyüjtés, melynek elsődleges módja hospitálás (óramegfigyelés) volt. Tanáronként kilenc órát látogattunk, melyekről három kivételével videó felvételt is rögzítettünk. Az órák egyenként körülbelül 50 percesek voltak. Ezek alapján hospitálási naplókat készítettünk, az alábbi szempontok szerint: az óra menete, az órán használt módszerek és eszközök, valamit egyéb megjegyzések (például feladatokra szánt időkeret, dicséreti módok, kiejtés fejlesztésére fektetett külön hangsúly stb.).

A hospitálási időszak után mindkét pedagógussal félig strukturált interjút készítettünk egy előre elküldött 22 kérdéses kérdőív alapján, mely Littlejohn (2011), Byrd (2001), Garinger (2002) és Tomlinson (2011) szempontjain alapult (1. Melléklet 1). A tényleges interjúk során a résztvevők válaszaik alapján további kérdéseket kaptak, melyek a témában való mélyebbre hatolást célozták. Mindkét interjút rögzítettük.

$\mathrm{Az}$ óramegfigyeléseken és az interjúkon kívül a taneszközöket is megvizsgáltuk, így például a Sunshine tankönyvcsalád harmadik kiadásának első és második kötetét, valamint az órán használt feladatlapokat is.

\subsection{Az adatelemzés módja}

A tankönyv és a Nemzeti Alaptanterv párhuzamainak vizsgálatához a Kairyudo kiadó $A$ Kairyudo jövőbeli céljai az angol oktatásban (Kairyudo, 2011), valamint Tájékoztató a 2012. évi alsó középiskolai angol tankönyvek tartalmáról (Kairyudo, 2012) címü kiadványait vetettük össze a Nemzeti Alaptanterv alsó középiskolai idegen nyelv-oktatásra vonatkozó részeivel $(M E X T, 2008)$.

Azt, hogy a kutatásban részt vevő pedagógusok hogyan értelmezik és építik be a tan- könyv egyes jellemzőit mindennapos tanári tevékenységükbe, elsősorban a hospitálási naplók, a videók és az interjú felvételek alapján vizsgáltuk. Az interjúk során elhangzott információkat nyolc kategóriába csoportosítottuk: (1) alkalmazhatóság, (2) a diákok motiválása, (3) a könyv szerkezete és az ismétlés mértéke, (4) témák, (5) feladatok és tevékenységek, (6) kiejtés, (7) a tanár motiválása, (8) tanári kézikönyvek. A videókat és a hospitálási naplókat a tanárok válaszainak alátámasztására használtuk.

Annak vizsgálatára, hogy a tanárok milyen módszerekkel és tartalmakkal egészítik ki a tankönyveket, újabb kategóriákat állítottunk fel az interjúkban említett tankönyvhasználati nehézségek alapján. Az interjúk anyagát a hospitálási naplókkal támasztottuk alá. Kategóriáink a következők voltak: (1) legyen motiválóbb a tankönyv, (2) legyenek érdekesebbek a feladatok, (3) több legyen az ismétlés, (4) több legyen a szókincsgyakorlás, (5) nagyobb hangsúlyt kapjon a kiejtés, a központozás és az intonáció fejlesztése, (6) a feladatok gondolkodásra és háttértudásuk előhívására ösztönözzék a diákokat, (7) túl könnyűek a hallott szövegértés feladatok, (8) érdekesebb ötletek legyenek a tanári kézikönyvben, (9) hasznosabb segédanyagok legyenek. A problémás területek azonosítása után feltérképezhettük, hogy a pedagógusok mivel egészítik ki óráikat, hogy a tankönyv hiányosságait ellensúlyozzák.

\section{Analízis}

\subsection{A Sunshine harmadik kiadásának összehasonlitása a jelenlegi Nemzeti Alaptantervvel}

A kutatás ezen része a Sunshine alábbi tulajdonságait vetette össze a Nemzeti Alaptantervvel: fó célkitűzések, alapvető szerkezet, témák, kiejtés, szótárhasználat, nyelvtan, szókincs. A tanulmányban található Sunshinenal kapcsolatos dokumentumokból valamint az Alaptantervből származó idézetek a szerző fordításai. 
Az alsó középiskolában használt angol tankönyvek szerepe...

\subsubsection{Fö célkitüzések, alapvetö szerkezet, és a Sunshine témái}

A diákok angol és más idegen nyelvek iránti érdeklődésének fejlesztéséért a Sunshine-t úgy tervezték meg, hogy ismétlődő sikerélményt nyújtson. Erre jelentenek példát a könyvben található My Project részek is, melyek lépésről lépésre vezetik el a diákokat egy-egy kitűzött célhoz. Az olyan témák, mint a bemutatkozás (első kötet), az egyetértés és egyet nem értés (második kötet) a kormány azon elvárásával hangzanak egybe, hogy a tananyag „fokozza a különféle látás- és gondolkodásmódok megértését, ezzel segítve a pártatlan ítélkezés képességének kialakulását" (MEXT, 2008). A diákok megtanulnak beszélni a hagyományos kultúráról is, igazodva az Alaptanterv azon kívánalmához, hogy a tankönyv mélyítse el a diákok megértését „a különféle életmódokról, Japán és más országok kultúrájáról, fokozza az érdeklődést a nyelv és a kultúra iránt, és tiszteletteljes magatartást alakítson ki ezekkel szemben" (MEXT, 2008).

A tankönyv témáit illetően a Nemzeti Alaptanterv azt javasolja, hogy sokszínűek, az adott korosztály érdeklődésének megfelelőek legyenek, „a világon élő emberek mindennapi életével, illemével és szokásaival, történeteivel, földrajzával, történelmével, hagyományos kultúrájával és természettudományával foglalkozzanak, különös tekintettel az angol ajkú emberekre és a japánokra" (MEXT, 2008). Így a Sunshine tankönyvek témái között megtalálható többek között a környezetvédelem, a japán hagyományok és kultúra megértése is. A második és harmadik évfolyam könyveiben morális oktatást célzó olvasmányokat is találunk, például a harmadik kötetben található, Teréz anyáról szóló szöveget.

\subsubsection{Kiejtés, szótárhasználat, nyelvtan és szókincs}

Az Alaptanterv szerint az órákon nagy gondot kell fordítani az angol és japán kiejtés különbségeire, a fonetikus szimbólumok tanítását azonban nem teszi kötelezővé. A Sunshine tankönyvcsalád a kiejtés fejlesztésére tartalmaz többek között CD utáni többszöri ismét- lésen alapuló feladatokat, a legtöbb oldal alján rövid, kiejtésre vonatkozó megjegyzéseket, Hatsuon Kurinikku ${ }^{3}$ részeket, és az olvasott szövegek után ötszintes, felolvasást számláló négyzeteket.

Az Alaptanterv szerint „a diákoknak meg kell ismerkedniük a szótárak használatával, hogy javukra tudják fordítani azokat" (MEXT, 2008). Ezzel összhangban a Sunshine első kötete tartalmaz egy oldalt az angol-japán szótár használatáról és szerkezetéről, a második kötet a különféle szófajokkal és többjelentésű szavakkal foglalkozik, míg a harmadik kötetben a többszavas igék (phrasal verbs) kerülnek terítékre. A függelékben a fonetikus szimbólumok is megtalálhatóak a szavak mellett, a fejezeteken belül azonban csak a második évtől jelennek meg.

Az Alaptanterv álláspontja szerint mivel a nyelvtan alátámasztja a kommunikációt, ezért azt úgy kell tanítani, hogy hatékonyan lehessen használni kommunikáció céljából. Kéri a tanárokat, hogy ne nyelvtani kifejezések magyarázatára és a különféle használati módokra fektessék a hangsúlyt, hanem az egyes nyelvtani elemek gyakorlati használata legyen a középpontban. Ezért a Sunshine minden rész elején egy egyszerű példán keresztül vezet be egy-egy nyelvtani elemet, melyet rövid, tömör japán magyarázat követ. Ezután az adott nyelvtant több lépésben sajátítják el a diákok, majd később az Eigo no shikumi ${ }^{4}$ és a $M y$ Project részek során átismétlik azt.

Az alsó középiskolai évek alatt elsajátítandó szókincs mértékét az Alaptanterv körülbelül 1200 szóban határozza meg (MEXT, 2008). A Sunshine tankönyvek szövegei és feladatai mind gyakran használt angol szavakból épülnek fel (Kairyudo, 2012). Az új szavakat feltüntetik az olvasmányok mellett, a diákok pedig apró négyzetekben jelölhetik be, hogy tisztában vannak-e már az adott szó jelentésével. A szókincs fokozatos gyarapítását az első évben sok párbeszéd és a Power-up

\footnotetext{
${ }^{3}$ Japánul: 発音クリニック, magyarul: Kiejtés Klinika

${ }^{4}$ Japánul: 英語のしくみ, magyarul: Az angol nyelv múködése
} 
Reading részek segítik, a második és harmadik évben a párbeszédek több olvasmánynyal egészülnek ki. Egyes fejezetek tartalmát Review Reading részek mélyítik el, harmadik évfolyamon pedig az Extensive Reading részek hosszabb olvasmányai a felvételi vizsgák szövegeihez szoktatják a diákokat.

\subsection{A tanárok hogyan értelmezik és épitik be a Sunshine tulajdonságait tanításukba}

\subsubsection{Alkalmazhatóság és a diákok motiválása}

Sakura szerint a tankönyv könnyen követhető, mivel van egy adott nyelvtani szerkezet, amit hallott szövegértés, gyakorlás és alkalmazás követ, egyéb feladatokkal kiegészülve. Szerinte az alappárbeszédek tankönyv végén található japán átirata segíthet a gyengébb tanulóknak lépést tartani az óra menetével, és a könyv alkalmat nyújt arra is, hogy a diákok egymást taníthassák. A tankönyvet alapjában véve motiválónak tartja, föleg a My Project részeket, de hozzátette, hogy a diákok motiváltságában a tankönyv nem játszik akkora szerepet. Shouta a tankönyvet önmagában nem találja motiválónak, viszont szerinte elérhető célok kitűzésével nagyban fokozható a diákok motiváltsága.

\subsubsection{Szerkezet és ismétlés}

A két tanár egyetértett abban, hogy a Sunshine tankönyvek szerkezete áttekinthető, jól követhetö, így akár egy pályakezdő is könnyen tud belőlük tanítani. Shouta külön kiemelte, hogy a tisztán elkülönülő nyelvtani és olvasott szövegértés részeknek köszönhetően a Sunshine könnyen alkalmazható a mindennapi tanítás során. Sakura szerint a tankönyv ismétlődő szerkezete a tanárnak és az alacsonyabb nyelvi felkészültségű diákoknak előny lehet, ugyanakkor a magasabb szinten lévő diákoknak talán nem annyira érdekes, hiszen nap mint nap ugyanazt kell végrehajtaniuk.

Mindketten egyetértettek abban, hogy a könyvekben található ismétlő részek nem elégségesek a diákok tudásának elmélyítéséhez. Shouta pozitívumként kiemelte, hogy a három projekt lehetőséget nyújt a korábban tanultak átismétlésére.

\subsubsection{Témák, feladatok és tevékenységek, kiejtés}

Sakura szerint a tankönyv egyes témái érdekesek és hasznosak, így például az origami, a nemzetközi ételfesztiválok, új diákok, és új barátok témakörei az első kötetben. Mindkét pedagógus egyetértett abban, hogy bizonyos témák túl nehezek lehetnek a tanulók számára, s nem felelnek meg az adott korosztály érdeklődésének. Konkrét példaként Sakura az újrahasznosítás témakörét emelte ki az első osztályosok esetében. Véleménye szerint vannak olyan témák is, amelyek a tanár számára okoznak nehézséget, hiszen még az Interneten is alig található róluk információ. Shouta szerint egyes témák túl komolyak a diákoknak, ugyanakkor hozzátette, hogy hisz tanulói képességében és abban, hogy még a nehéz topikok is képesek gondolatokat ébreszteni bennük.

A két tanár szerint egyes feladatok nem motiválják tanítványaikat. Shouta időnként lecseréli a tankönyvben található beszéd- és íráskészség feladatokat, hogy jobban le tudja kötni diákjai figyelmét. Mindketten egyetértettek abban, hogy a hallott szövegértés feladatok többsége túl könnyü, hiszen nagy részük csupán egy helyes válasz kiválasztását, vagy egy kulcsszó beírását követeli meg, annak ellenére, hogy a felvételi vizsgákon nehezebb és hosszabb hallott szövegek megértését várják el a diákoktól.

Sakura szerint a tankönyv feladatai nem igazán ösztönzik gondolkodásra, tárgyalásra, háttértudásuk alkalmazására a diákokat. Olyan témák, mint például a manga vagy az anime jobban motiválnák őket. Shouta szerint egyes feladatok elgondolkodtatóak, mint például a második kötet Program 10 (So Many Countries, So Many Customs) része, a telefonos vagy vásárlós részek pedig a diákok tárgyalókészségét is fejleszthetik.

A pedagógusok véleménye megegyezett abban, hogy a kiejtés elsajátítása nagyon nehéz diákjaik számára. Sakura szerint a tan- 
Az alsó középiskolában használt angol tankönyvek szerepe...

könyv nem tartalmaz megfelelő mennyiségü feladatot az angolul tanuló japán anyanyelvű diákok speciális nehézségeinek leküzdéséhez. Esetenként hosszúnak és túl nehéznek találja a kiejtés fejlesztését célzó Hatsuon Kurinikku szekciót. Felmerült, hogy az első osztályos tankönyv nem tartalmazza a szövegek melletti új szavak esetében a fonetikus szimbólumokat, ami Sakura szerint a diákok javára válna. Tanulói szeretik a ritmikai részeket, mert ezek folyamán használhatják a testüket is. Shouta felhívta a figyelmet az oldalak alján található fonetikai sarkokra, melyeket ő csak alkalmanként vesz igénybe. Általánosságban azt gondolja, hogy a Sunshine elég támogatást nyújt a kiejtés gyakorlásához, és a második osztályos könyvben már megtalálható fonetikus szimbólumok is segíthetik a diákokat.

\subsubsection{A tanár motiválása és a tanári kézikönyvek}

Sakura szerint ez a könyv kihívás lehet a tanár számára. S bár elmondása szerint szeretne szórakoztatóbb módon angolt tanítani és tanulni, azt az elvárást is teljesítenie kell, hogy diákjai magas pontszámokat érjenek el a felvételi vizsgákon. Shouta szeret a Sunshine tankönyvcsaládból tanítani, de időnként olyan érzése van, hogy túl sok szó található egy oldalon, ami nehézséget okozhat tanulóinak.

Mindketten azt szeretnék, hogy a tanári kézikönyvek több ötletet tartalmazzanak arra vonatkozóan, hogy hogyan alakítsák át óráikat különféle igényű csoportjaik számára. Sakura néha elolvassa a kézikönyvet, de nem használja gyakran, mert ha megtenné, az már nem az ő órája lenne. Korábban követte a kézikönyv útmutatásait, de az abban található óratervi javaslatokat nem fogadták jól diákjai, ezért módosította őket. Shouta ritkán használja a kézikönyveket, mert a bennük található óratervek nem megfelelőek tanulói számára. Tanárként segítségére van a segédanyagokban megtalálható japán jelentés, szókincs és némi háttér-információ, ezért alkalmanként használja a kézikönyvet és a tankönyvcsaládot kiegészítő tesztfüzetet is.

\subsection{A két pedagógus stratégiái a Sunshine kiegészítésére}

\subsubsection{Legyenek motiválóbbak a tankönyvek és érdekesebbek a feladatok}

A tankönyv feladatai közül nem mindegyik kelti fel a két tanár diákjainak érdeklődését, így ezeket a részeket vagy átugorják, vagy kicserélik Interneten talált, illetve saját ötletekkel. Óráikon rendszeresen alkalmaznak kortárs hírességekkel, érdekes tényekkel kapcsolatos ötleteket a könyv anyagához kapcsolódva. Sakura hangsúlyozta az aktív tanulás és a kreatív feladatok fontosságát az órán, így például esetenként diákjainak saját kvízüket kell elkészíteniük egy hallott szövegértés feladat alapján. Shouta a feladatok nehézségi szintjéről megjegyezte: fontos az egyensúly, ezért a feladatoknak sem túl könnyünek sem túl nehéznek nem szabad lenniük.

A feladatok érdekesebbé tételének módszereként értelmezhetőek a különféle csoportalakítási technikák is. Így a diákoknak alkalmuk nyílik az órán padtársukkal, az előttük- és mögöttük ülővel párban, vagy akár három-négyfős kis csoportokban dolgozni, de egy szerepjáték alkalmával a kis csoportok azonos szerepet betöltőiből is alakulhat újabb csoport, hogy megbeszélhessék személyes tapasztalataikat.

\subsubsection{Több legyen az ismétlés és a szókincsgyakorlás}

Mindketten kevésnek találják a tankönyvben az ismétlést. A megtanulandó szavak és kifejezések egy része problémát okoz tanulóiknak, és ezek mennyiségét is sokallják. Ennek orvoslására számos technikát alkalmaznak: előfordulnak szókincs kvízek, korábbi anyagok hangos felolvasása, többjelentésü szavak tisztázása, japán megfelelők megbeszélése. Ezen kívül párban gyakoroltatják minden óra elején az adott fejezet új szavait, illetve szókártyákkal és képekkel segítik elő a korábbi tananyag felelevenítését.

Nyelvtani ismétlésként mindkét tanár megértést ellenőrző kérdéseket alkalmazott a diákok már meglévő tudásának előhívására. 
Számos esetben a tanulóknak egymás hibáit kellett kijavítaniuk, így ellenőrizve a szóban forgó nyelvtani elem, elemek megértését.

\subsubsection{A kiejtés, az intonáció, a központozás fejlesztése, és a diákok elgondolkodtatása}

A kiejtés és az intonáció fejlesztésére használt technika volt a szavak, kifejezések, mondatok többszöri ismétlése. Külön figyelmet kaptak a katakana szavak (például 'rookaru's és 'local'), a betűzés (például 'b' és 'd') és a központozás (például kérdőjelek). A kiejtés gyakoroltatására mindkét tanár változatos olvasási mintákat használt. Alkalmazták az úgynevezett slash reading technikát, amikor a tanár felolvasása közben a diákok bejelölték a szünetek helyét, majd ezeknek megfelelően olvastak. Shouta óráján elöfordult a back formation technika is, mely során egy szóból kiindulva, egyre hosszabb részeket ismételve fokozatosan építették fel a mondatokat. Sakura óráin a diákok kézzel ütötték a szavak ritmusát, egymás helyes válaszait elismételték, vagy betűzés közben betűnként fedte fel a szavakat a tanár, miközben a diákok olvastak.

A tanulók háttértudásának aktiválására mindkét pedagógus használta az ötletbörze (brainstorming) módszerét, többnyire képek segítségével. A diákok kulturális ismereteinek előhozására például Sakura megkérdezte, hogyan veszik fel a telefont az angolok és a japánok. Shouta gyakran használt a diákok meglévő ismereteire irányuló példamondatokat. A "Which is longer, the Amazon River or the Nile?"' kérdés kapcsán például a nyelvtanilag helyes válasz megfogalmazása után a pontos adatokat is tisztázták.

Mindketten rendszeresen megkérdezték diákjaikat, hogy hogyan olvasnának egy-egy bizonyos szöveget, van-e benne fokozott odafigyelést igénylő rész. Így amikor Sakura óráján a tanulók egy telefonbeszélgetést olvastak (első kötet, 95.o.), melyben a kisfiú odakiált az anyu-

\footnotetext{
${ }^{5}$ Japánul: ローカル

${ }^{6}$ Magyarul: Melyik hosszabb: az Amazonas folyó, vagy a Nílus?
}

kájának, hogy őt keresik, megállapították, hogy ezt a részt hangosabban kell olvasni, mert az édesanya egy másik szobában van. Ez a gyakorlat is a gondolkodásra ösztönzés egy formájának tekinthető, és az intonációt is fejleszti.

\subsection{4 Ötletek az órák szinesítésére, egyéb segédanyagok használatára}

Az órák érdekesebbé tételéhez Sakura fontosnak tartja az óra elején zajló bemelegítő szóbeli kommunikációt. Erre volt példa az első percekben a dátum és az időjárás megbeszélése is, melyet mindkét tanár alkalmazott. Sakura azt is hozzáfüzte, hogy amikor kivetítőt, dalokat vagy képeket használ, tapasztalata szerint a diákokat jobban leköti az óra. Időnként Shouta is használ kivetítőt, számítógépet és dalokat, ezzel igyekszik lebilincselőbbé tenni óráit. A hospitálás idején több ízben háttérzenét játszott le a CD-lejátszón mialatt a diákok memorizáltak vagy önállóan dolgoztak.

Kiegészítő anyagként mindkét pedagógus rendszeresen készít saját szólistákat és gyakorló feladatlapokat diákjainak.

\section{Konklúzió}

A tanulmány első részében arról esett szó, hogy a Sunshine tankönyvsorozat harmadik kiadása mennyire van összhangban a jelenlegi Nemzeti Alaptantervvel, majd megvizsgáltuk, hogy a tanárok hogyan alkalmazzák a tankönyvet mindennapos oktató tevékenységük során. Arra a következtetésre jutottunk, hogy a tankönyv megfelel az Alaptanterv elvárásainak és a kommunikatív nyelvoktatás alapelveit követi, azonban az óralátogatások és az interjúk rávilágítottak annak szükségére, hogy a pedagógusok csoportjaik nyelvi felkészültségét, igényeit és érdeklődését figyelembe véve átalakítsák és kiegészítsék a tankönyvet a minél hatékonyabb nyelvtanulás érdekében.

Bár nem lehet messzemenő általánosításokat levonni két tanár esettanulmányából, jelen tanulmány azt mutatja, hogy a pedagógusok igyekeznek egyfajta kommunikatív megközelítést előtérbe helyezni tanításukban. 
Az alsó középiskolában használt angol tankönyvek szerepe...

\section{Köszönetnyilvánítás}

A tanulmány írója ezúton szeretné megköszönni Sakura és Shouta odaadó részvételét a kutatásban, diákjaik közreműködését, továbbá James M. Hall professzor társszerzőként végzett áldozatos munkáját az angol nyelven megjelent eredeti tanulmányban.

\section{Felhasznált irodalom}

Aspinall, R. W. (2006): Using the paradigm of 'small cultures' to explain policy failure in the case of foreign language education in Japan. Japan Forum, 18. 2. sz., 255-274. https://doi.org/10.1080/09555800600731197

Butler, Y. G. (2011): The Implementation of Communicative and Task-Based Language Teaching in the Asia-Pacific Region. Annual Review of Applied Linguistics, 31. 36-57. https://doi.org/10.1017/S0267190511000122

Byrd, P. (2001): Textbooks: Evaluation for Selection and Analysis for Implementation. In: Celce-Murcia, M. (ed.) Teaching English as a second or foreign language. Heinle \& Heinle, Boston. 415-427.

Fekete, R. \& Hall, J. M. (2015): The Role of Junior High School English Textbooks in Communicative Language Teaching Based on a Case Study of Two Junior High School Teachers Teaching Sunshine. Iwate daigaku kyouikugakubu fuzoku kyouikujissen sougousentaa kenkyuu kiyou, 14. 241-255.

Gakusho. (2012): Heisei 24 nendo kyoukasho saitaku ichi ran hyou [Az iskolák által választott tankönyvek 2012-es listája].

URL: http://www.gakusho.com/tokuho/ saitaku.html (Utolsó letöltés: 2014.12.30.)

Garinger, D. (2002): Textbook Selection for the ESL Classroom. Eric Digest.

URL: http://www.cal.org/content/ download/1573/16778/file/TextbookSelecti onfortheESLClassroom.pdf (Utolsó letöltés: 2014.12.28.)

Gorsuch, G. (2000): EFL Educational Policies and Educational Cultures: Influences on Teachers' Approval of Communicative Activities.
TESOL Quarterly, 34. 4. sz., 675-710.

https://doi.org/10.2307/3587781

Humphries, S. \& Burns, A. (2015): 'In reality it's almost impossible': CLT-oriented curriculum change. ELT Journal, 69. 3. sz., 239-248. https://doi.org/10.1093/elt/ccu081

Kairyudo (2011): Kairyudo ga mezasu korekara no eigokyouiku [A Kairyudo jövőbeli céljai az angol oktatásban].

URL: http://www.kairyudo.co.jp/general/ data/contents/02-chu/eigo/h24/20110330mezasumono.pdf (Utolsó letöltés: 2014.12.30.)

Kairyudo (2012): Heisei 24nendoyou chuugakkou eigo kyoukasho naiyouannai. Sunshine English Course 1 [Tájékoztató a 2012. évi alsó középiskolai angol tankönyvek tartalmáról. Sunshine angol kurzus 1].

URL: http://www.kairyudo.co.jp/general/ data/contents/02-chu/eigo/h24/h24-naiyou. pdf (Utolsó letöltés: 2014.12.30.)

Littlejohn, A. (2011): The analysis of language teaching materials: inside the Trojan Horse. In: Tomlinson, B. (ed.) Materials Development in Language Teaching. Cambridge University Press, Cambridge, UK, 179-211.

MEXT (2008): Courses of Study, Lower Secondary School, Foreign Languages.

URL: http://www.mext.go.jp/ component/english/__icsFiles/afield file/2011/03/17/1303755_013.pdf (Utolsó letöltés: 2014.12.28.)

Niisato, M. \& mtsai (2011): Sunshine English Course. Kairyudo, Tokyo.

Nishino, T. \& Watanabe, M. (2008): Communication-oriented policies versus classroom realities in Japan. TESOL Quarterly, 42. 2. sz., 133-138. https://doi.org/10.1002/j.1545-7249.2008.tb00214.x

Sakui, K. (2004): Wearing two pairs of shoes: language teaching in Japan. ELT Journal, 58. 2. sz., 155-163.

https://doi.org/10.1093/elt/58.2.155

Tomlinson, B. (2011): Materials Development. In: Burns, A. és Richards, J. C. (eds.) The Cambridge Guide to Pedagogy and Practice in Second Language Teaching. Cambridge University Press, Cambridge, UK, 269-278. 


\section{Melléklet 1.}

\section{Az interjú kérdései angolul}

\section{Warm-up questions}

1. How long have you been an English teacher?

2. What grades are you teaching in?

3. What are the most important goals and aspects of teaching for you? What does it mean for you to be a teacher?

4. Can you tell me about Class 2-4 (or Class 1-3)? (for example attitude towards English, weak points, strong points, special needs, relations with each other, relations with the teacher etc.)

\section{General questions about Sunshine}

5. Sunshine is the textbook that most junior high schools in Iwate Prefecture use. Do you think that Sunshine is easily adaptable for different groups with different needs?

6. How long have you been teaching Sunshine? How do you find it compared to New Horizon?

7. Would you say that Sunshine is a textbook that motivates English learning? If yes, in what ways? If not, do you have any ideas how to make it more motivating?

\section{Structure and content}

8. What is your opinion about the structure of the book? If you could, would you like to make any adjustments in content and/ or sequencing to better fit the course and the needs of your students?

9. What is your opinion about the topics covered in Sunshine? (for example: Are they motivating? Appropriate for this age group? Any topics that you would rather replace or would consider it a good idea to be included? Difficulty of vocabulary? etc.)

10. In your opinion, do the tasks of Sunshine make the students think, negotiate, or utilize their background knowledge? If so, in what ways?
11. It is often mentioned that pronunciation is especially hard for Japanese students. Do you agree?

12. Do you find that the book provides sufficient guidance on English pronunciation? In what ways is pronunciation practice included in your lessons?

13. What are aspects of learning English that your students are having difficulties with? Does the textbook support you with enough tasks to overcome these difficulties? (for example listening, certain kinds of grammar etc.)

\section{Teaching Sunshine}

14. As a teacher, how motivated and challenged do you feel while teaching Sunshine?

15. To what extent does the Teacher's Book let you utilize your own teaching style and ideas? Would you say that the textbook is in unison with your own teaching principles? Does it support your work?

16. How do you implement the suggestions of the Teacher's Book into your lessons?

17. Do you ever add tasks or make materials besides the suggestions of the Teacher's Book? (for example word lists, activities etc.)

18. Does the Teacher's Book and other materials of Sunshine provide you with enough alternatives to customize your lessons to your different groups?

19. What is your opinion about including modern technology in the classroom?

20. What is it that you would like to change about the book or its support materials to make it more teacher-friendly?

21. What is it that you would like to change about the book or its support materials to make it more student-friendly?

22. Any additional comments about the textbook are welcome. 


\section{The Role of Junior High School English Textbooks in Communicative Language Teaching Based on a Case Study of Two Junior High School Teachers Teaching Sunshine}

One of the junior high school English textbook series approved by the Japanese Ministry of Education, Culture, Sports, Science and Technology (MEXT) is Sunshine, published by Kairyudo. This case study of two Japanese junior high school teachers using Sunshine in Iwate Prefecture addresses three aspects: what features the textbook contains to meet the requirements of the Course of Study, how the two teachers perceive and implement certain features of the textbook into their everyday teaching practice, and what classroom practices they employ to supplement the textbook. For the research, the official guide booklet of Sunshine and an additional pamphlet were examined, and then research data was collected via class observation, field notes, semi-structured interviews and classroom artifacts. Research concluded that Sunshine is, in principal compatible with a communicative approach, but teachers pursuing a CLT-like approach will need to supplement the textbook with their own ideas.

Keywords: Communicative Language Teaching, Sunshine English Course, English teaching in Japan, Junior High School English textbooks, Japanese Course of Study

Fekete Réka (2019): Az alsó középiskolában használt angol tankönyvek szerepe a kommunikatív nyelvoktatásban két Sunshine-ból tanító alsó középiskolai tanár esettanulmánya alapján. Gyermeknevelés, 7. 1. sz., 99-107. 